\title{
Population dynamics of spotted stem borer, Chilo partellus (Swinhoe) and its interaction with natural enemies in sorghum
}

\author{
K. Divya ${ }^{1}$ K.N. Marulasiddesha ${ }^{2}$, K. Krupanidhi ${ }^{1}$ and M. Sankar ${ }^{3}$ \\ ${ }^{1}$ T-John College of Pharmacy, Kammanahalli, Bangalore, KA, India \\ ${ }^{2}$ College of Agriculture, University of Agricultural Science, Dharwad, KA, India \\ ${ }^{3}$ University of Agriculture Science, GKVK Campus, Bangalore, KA, India. \\ kdivya49@gmail.com, siddesh2575@gmail.com, shankarms10@gmail.com, krupanidhi_k@rediffmail.com
}

\begin{abstract}
Sorghum stem borer, Chilo partellus Swinhoe is one of the serious pests of sorghum and maize crops in Asia and throughout East and South Africa. In India, it is becoming as the most damaging insect pest particularly in Dharwad region of north Karnataka by causing economic losses during kharifand rabi seasons. The observations on population dynamics of egg masses, larvae, pupae, number of plant damaged and parasitic interactions of natural enemies with larvae and pupae of $C$. partellus were recorded at weekly interval at Dharwad (Karnataka). The stem borer population was significantly higher in kharif than in rabi-summer crop. The larval parasitoid, Cotesia flavipes was found to be very active in kharif season and maximum parasitization of $29 \%$ was recorded in November whereas Sturmiopsis inferens was prevalent during rabi-summer crop and maximum parasitization of $28 \%$ was recorded during February. A population of $2 \%$ pupal parasitoid, Tetrastichus sp., was also recorded during kharifseason.
\end{abstract}

Keywords: Biological control, Chilo partellus, population dynamics, stem borer.

Introduction

Sweet sorghum, Sorghum bicolor (L.) Moench is grown in the rainy as well as post rainy seasons, generally by resource poor farmers in the semi-arid regions of the world particularly Asia, East and South Africa. Sorghum is the staple food crop in Dharwad region of north Karnataka districts in India. It is grown in the rainy (July-Oct), late rainy (Aug-Dec) and post rainy seasons. Sorghum crop is being attacked by nearly 150 insect species causing an annual loss of over $\$ 1$ billion in the Semi Arid Tropics (ICRISAT, 1992) and the most damaging species are Chilo partellus, Busseola fusa and Eldana saccharina (Songa et al., 2001). De Groote et al. (2003) found that all stem borer species caused average annual losses of $13.5 \%$, valued at US\$ 80 million.

In India, a number of stem borer species have been reported as serious pests of sorghum crop of which spotted stem borer, Chilo partellus (Swinhoe) (Lepidoptera: Pyralidae) is important (Jotwani et al., 1971). Durden (1953) from Kongwa recorded more than $35 \%$ infestation of $C$. partellus on sorghum and maize and also observed that the peak population of pests appears during middle of June. In Maharashtra, number of stem borer larvae were found to be high in winter sorghum than in kharif sorghum but the average number of pupae, percentage of stem tunneling and inter nodes attacked were highest only in rainy (kharif) season (Anonymous, 1987). Singh and Sharma (1984) observed $4-45 \%$ infestation of $C$. partellus in sorghum and maize and maximum infestation was observed during August, which declined gradually in Sep. and Oct. Mohan et al.
(1990) recorded the highest seasonal incidence of $C$. partellus on variety $\mathrm{HC}-136$ and JS-20 during rabisummer and kharif and larvae and pupae populations was found to be high during kharif season crop than in rabi-summer. And the mean larval population varied from 10 to 32 per sq. on JS-20 and 15 to 36 per sq. on HC-136 and they also observed the peak population of the pest from $3^{\text {rd }}$ week of August to $2^{\text {nd }}$ week of Sep. During the off-season, when there are no cultivated crops in the field, in addition to the hibernating or diapausing populations in crop residues stem borers remain present on wild host plants and can infest the cereal crops.

There is no permanent solution to control this pest except chemical control. However, biocontrol agents such as, parasitoids, predators and pathogens suppressed the population outgrowth of $C$. partellus but their activity was not enough to reduce the pest populations below the economic damage level. Mote (1988) correlated the degree of damage by stem borer with grain yield. According to him, percent plants infested by $C$. partellus at harvest were 9,5 and 9 in rabi cultivars CSH-8R, SPV86 and $M-35-1$, respectively. Further he reported that there was a significant negative correlation between percent stems tunneling by larvae of $C$. partellus and grain yield. Now, there are reports of tremendous success by utilizing biological control methods in agricultural ecosystem (Parrella et al., 1999). During our study we have identified three indigenous endoparasitoids such as, Cotesia flavipes, Sturmiopsis inferens and Tetrastichus sp., which were found attacking the larvae and pupae of C. partellus in Kharif and rabi-summer seasons crops at
Research article

(CIndian Society for Education and Environment (iSee)
"Sorghum stem borer" http://www.indjst.org
Divya et al. Indian J.Sci.Technol. 
Dharwad region of north Karnataka, India. These parasitoids are probably more habitat specific with regard to foraging for hosts than they are host-specific as they appear to have moved from their indigenous hosts to use C. partellus as a new alternative host. Devi and Raj (1996) reported 35 to 50\% parasitization by Apanteles sp. on larvae of $C$. partellus during the second week of October in sorghum in Himachal Pradesh. The parasitic effects of larval parasitoid, $S$. inferens and $C$. flavipes on larvae of $C$. partellus were reported by several authors (Usman \& Puttarudriah, 1955; Sharma et al., 1966; Krishnamurthy \& Usman, 1954). Barpete \& Shinde (1991) studied the seasonal occurrence of Apanteles flavipes on C. partellus larvae in Madhya Pradesh and observed their population from July to Nov with a peak activity during the first half of Oct in 1989 and Aug to Nov, 1990 and reported 1 to $9 \%$ parasitism during the two years. Later, Mohan et al. (1990) reported 2-33\% parasitization of $C$. partellus larvae by $A$. flavipes followed by Bracon chinensis (0.2-4\%) and Stenobracon sp. $(0.2-4 \%)$ at Hissar and these parasitoids remained active during $3^{\text {rd }}$ week of Aug to $1^{\text {st }}$ week of Sep. Keeping the above problems and prospects in view, the present investigations was undertaken to study the population dynamics of $C$. partellus and its interaction with natural enemies in sorghum ecosystem at Dharwad region in kharif and rabi-summer seasons in the year 2005-06.

\section{Materials and methods}

The field and laboratory experiments were conducted on C. partellus, with reference to its population dynamics and interaction with their natural enemies on sweet sorghum during 2005-06 in black soil at main Research Station, Dharwad (situated at $15^{\circ} 20^{\prime} \mathrm{N}$ latitude and $75^{\circ}$ 07' longitude and at an altitude of $678 \mathrm{~m}$ above the mean sea level) Karnataka, India. The sorghum variety SSV-74 was sown in the last week of July ( $31^{\text {st }}$ standard week) and in October ( $45^{\text {th }}$ standard week) covering an area of 0.1 ha. The observations on population dynamics of egg masses, larvae, pupae and number of plant damaged were recorded at weekly interval. The parasitic interactions with larvae and pupae of $C$. partellus were recorded at weekly interval and observations were taken from one week after sowing ( $32^{\text {nd }}$ standard week) and continued upto last week of March $\left(13^{\text {th }}\right.$ standard week). To study the population of natural enemies from larvae and pupae, the stem borer infested sweet sorghum plants were collected from the sorghum cultivated field two times during $1^{\text {st }}$ week of October $\left(40^{\text {th }}\right.$ standard week) and $2^{\text {nd }}$ week of Jan ( $2^{\text {nd }}$ standard week) and then the larvae and pupae were carefully isolated. The collected larvae were then reared in artificial diet as described by Shorey \& Hale (1965). Each larva was released in artificial diet $(25 \mathrm{~g})$ contain separate plastic vial $(2.0 \mathrm{~cm}$ dia. and $7.5 \mathrm{~cm}$ length) and the vials were loosely closed with cotton plug and kept at $28 \pm 2^{\circ} \mathrm{C}$. The parasitoids thus emerged from field collected larvae and pupae were preserved and identification services were availed at Project Directorate of Biological Control (PDBC), Bangalore, India. Data were analysed and subjected to ANOVA or factorial analysis of variance (FANOVA) and statistical significance was judged at the level $(P<0.05)$.

\section{Results}

\section{Population dynamics of sorghum stem borer}

Fig 1. Percent damages caused on sweet sorghum due to $C$. partellus incidence and their parasitic interaction during kharif season

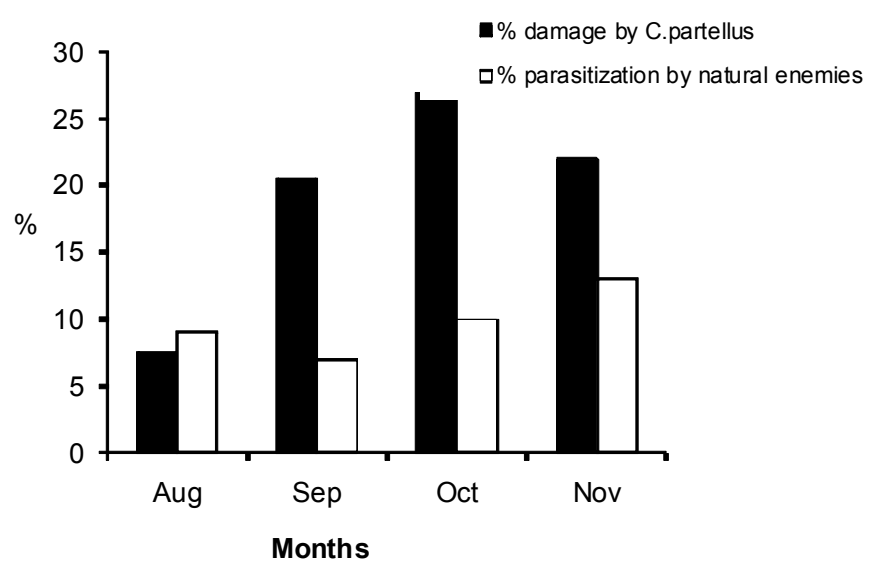

Three indigenous natural enemies' viz., C. flavipes, $S$. inferens and Tetrastichus sp. were observed in parasitized larvae and pupae of sorghum stem borer. Maximum number of egg masses was recorded on $37^{\text {th }}$ standard week (7 egg masses/50 plants) which was followed by $36^{\text {th }}$ standard week (5 egg masses $/ 50$ plants). Egg masses were not observed during $32^{\text {nd }}, 45^{\text {th }}$ and $47^{\text {th }}$ standard week. Whereas, in rabi-summer the highest number of egg masses was collected in $50^{\text {th }}$ standard week followed by $49^{\text {th }}$ standard week ( 4 egg masses $/ 50$ plants). However egg masses were not seen during $7^{\text {th }}$, $8^{\text {th }}, 10^{\text {th }}, 11^{\text {th }}, 12^{\text {th }}$, and $13^{\text {th }}$ standard weeks (Table $1 \& 2$ ). During kharif season, more number of larvae (30 larvae/50 plants) was noticed during $40^{\text {th }}$ standard week followed by $39^{\text {th }}$ standard week (26 larvae/50 plants) and

Fig 2. Percent damages caused on sweet sorghum due to

C. partellus incidence and their parasitic interaction during rabi-summer season

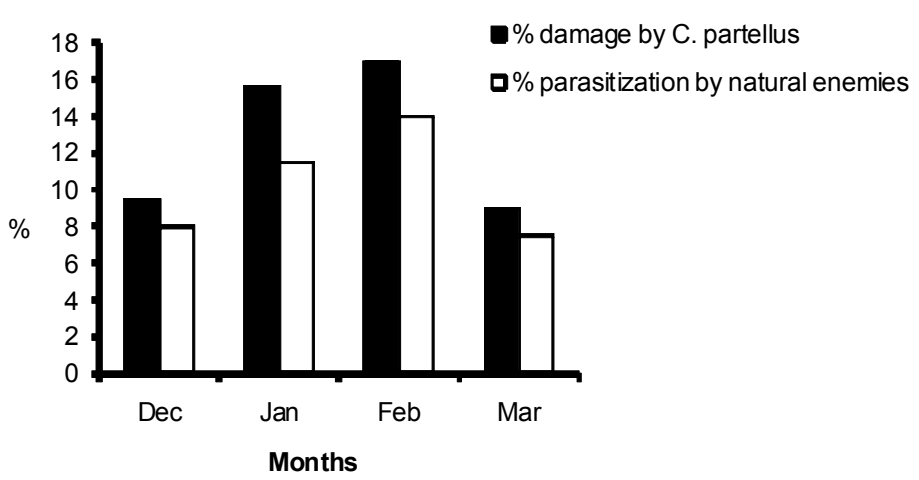

it was recorded less number (4 larvae/50 plants) during
Research article

(c)Indian Society for Education and Environment (iSee)
"Sorghum stem borer" http://www.indjst.org
Divya et al. Indian J.Sci.Technol. 
$32^{\text {nd }}$ standard week. However larval population was more (19 larvae/50 plants) in $3^{\text {rd }}$ and $9^{\text {th }}$ standard week followed by $8^{\text {th }}$ standard week ( 17 larvae/50 plants) and was less (4 larvae/50 plants) during $49^{\text {th }}$ standard week during rabi- summer season. Maximum number of pupae (19 pupa/50 plants) were recorded during $44^{\text {th }}$ standard week followed by $47^{\text {th }}$ standard week (18 larvae/50 plants) while no pupae was collected from $32^{\text {nd }}$ to $35^{\text {th }}$ standard week during kharif season. Whereas, in rabi-summer season pupal population was observed less in number (11 pupa/plants) were collected during $9^{\text {th }}$ and $10^{\text {th }}$ standard week while no pupa were collected from $49^{\text {th }}$ to $52^{\text {nd }}$ standard week (Table $1 \& 2$ ).

\section{Percent damage}

Maximum number of plants (38\%) was infested during $40^{\text {th }}$ standard week followed by $39^{\text {th }}$ standard week $(32 \%)$ with $44^{\text {th }}$ standard week. Whereas the parasitization by pupal parasitoid, Tetrastichus sp. was observed $7 \%$ and $6 \%$ during $43^{\text {rd }}$ and $45^{\text {th }}$ standard week in kharif whereas, in rabi-summer season crop no pupal parasitoids was observed (Table 1). The result of our study revealed that C. partellus population was significantly high in kharif season than in rabi-summer season crops. Infestation and percent damage caused by stem borers were significantly high compared with the parasitic effect of natural enemies in kharif than in rabi-summer season. It may be attributed that the low temperatures are more suitable for stem borer infestations and it leads to higher damage on crop than parasitic interaction (Fig. 1). Whereas, in rabi-summer the interactions between pest's infestation/ damage and the parasitic effects were on par, it leads to low percentage of crop damage. Hence, the during kharif season. However in rabi-summer it was $20 \%\left(3^{\text {rd }}\right.$ and $8^{\text {th }}$ standard week) followed by $18 \%$ $\left(9^{\text {th }}\right.$ standard week) and $4 \%\left(32^{\text {nd }}\right.$ standard week) (Table 1\&2). The peak infestation (27\%) was observed during October while, it was minimum (7.5\%) during August (Table 1) in kharif season. However, in rabi-summer crop mean monthly percent incident of the pest was maximum (17\%) during kharif while, it was minimum (9\%) during March in rabi-summer (Table 2).

\section{Natural enemies of stem borer}

During the study we have observed three indigenous endoparasitoids such as, two larval parasitoids, viz. Cotesia flavipes (Cameron) (Braconidae: Hymenoptera) and Sturmiopsis inferens (Townsend) (Tachinidae: Diptera) and one from pupae Tetrastichus sp. Eulophidae: Hymenoptera) during kharif and rabi-summer seasons crop.

Larval parasitoid, C. flavipes was more active $(35 \%$ parasitization) during $45^{\text {th }}$ standard week followed by $44^{\text {th }}$ standard week $(33 \%)$ while no activity was noticed from $32^{\text {nd }}$ to $34^{\text {th }}$ standard Table 1. Population dynamics of Chilo partellus and its natural enemies in sweet sorghum ecosystem during kharif.

\begin{tabular}{|c|c|c|c|c|c|c|c|c|c|}
\hline \multirow[b]{2}{*}{$\begin{array}{c}\text { Date of } \\
\text { observation }\end{array}$} & \multirow[b]{2}{*}{$\begin{array}{l}\text { Standard } \\
\text { week }\end{array}$} & \multirow{2}{*}{$\begin{array}{c}\text { No. Of } \\
\text { egg } \\
\text { masses }\end{array}$} & \multirow{2}{*}{$\begin{array}{c}\text { No. } \\
\text { of } \\
\text { larvae }\end{array}$} & \multirow{2}{*}{$\begin{array}{c}\text { No. of } \\
\text { pupa } \\
\text { e }\end{array}$} & \multirow{2}{*}{$\begin{array}{c}\text { No. of } \\
\text { plant } \\
\text { infested }\end{array}$} & \multirow{2}{*}{$\begin{array}{c}\% \\
\text { damage }\end{array}$} & \multicolumn{3}{|c|}{$\begin{array}{c}\% \text { parasitization of } \\
\text { natural enemies }\end{array}$} \\
\hline & & & & & & & $\mathrm{Cf}$ & $\mathrm{Si}$ & $\begin{array}{c}\text { Tetra- } \\
\text { stichus } \\
\text { sp. }\end{array}$ \\
\hline $9-8-2005$ & 32 & 0 & 4 & 0 & 2 & 4 & 0 & 0 & 0 \\
\hline $16-8-2005$ & 33 & 3 & 5 & 0 & 3 & 6 & 0 & 0 & 0 \\
\hline $23-8-2005$ & 34 & 2 & 8 & 0 & 5 & 10 & 0 & 0 & 0 \\
\hline $30-8-2005$ & 35 & 3 & 9 & 0 & 5 & 10 & 11.0 & 0 & 0 \\
\hline Mean & & 0.04 & 0.13 & 0.00 & & 7.58 & 2.78 & 0 & 0 \\
\hline $6-9-2005$ & 36 & 5 & 12 & 0 & 7 & 14 & 16.7 & 0 & 0 \\
\hline 13-9-2005 & 37 & 7 & 15 & 2 & 8 & 16 & 13.3 & 0 & 0 \\
\hline 20-9-2005 & 38 & 3 & 17 & 3 & 10 & 20 & 23.5 & 0 & 0 \\
\hline 27-9-2005 & 39 & 2 & 26 & 4 & 16 & 32 & 31.0 & 0 & 0 \\
\hline Mean & & 0.09 & 0.35 & 0.05 & & 20.5 & 21.08 & 0 & 0 \\
\hline 4-10-2005 & 40 & 3 & 30 & 7 & 19 & 38 & 26.7 & 0 & 0 \\
\hline $11-10-2005$ & 41 & 2 & 17 & 9 & 13 & 26 & 23.5 & 0 & 0 \\
\hline $18-10-2005$ & 42 & 3 & 16 & 13 & 12 & 24 & 25.0 & 0 & 0 \\
\hline $25-10-2005$ & 43 & 2 & 14 & 15 & 10 & 20 & 21.4 & 0 & 0 \\
\hline Mean & & 0.05 & 0.39 & 0.22 & & 27.00 & 24.16 & 0 & 1.7 \\
\hline 1-11-2005 & 44 & 1 & 15 & 19 & 9 & 18 & 33.3 & 0 & 0 \\
\hline $8-11-2005$ & 45 & 0 & 17 & 16 & 11 & 22 & 35.3 & 12.5 & 6.3 \\
\hline $15-11-2005$ & 46 & 1 & 10 & 17 & 10 & 20 & 30.0 & 0 & 0 \\
\hline 22-11-2005 & 47 & 0 & 13 & 18 & 12 & 24 & 23.1 & 16.7 & 0 \\
\hline $29-11-2005$ & 48 & 1 & 9 & 6 & 13 & 26 & 22.2 & 0 & 0 \\
\hline Mean & & 0.01 & 0.26 & 0.3 & & 22 & 28.8 & 5.9 & 1.3 \\
\hline
\end{tabular}

Cf-Cotesia flavipes; Sf-Sturmiopsis inferens

parasitic interactions become more in summer crop than weeks during kharif. However, in rabi-summer the maximum parasitic activity $(32 \%)$ was noticed only in $50^{\text {th }}$ standard week. Significantly, highest parasitization (37\%) was recorded by the larval parasitoid, $S$. inferens on $C$. partellus larvae during $6^{\text {th }}$ standard week followed by $3^{\text {rd }}$ standard week (32\%) in rabi-summer crop. But in kharif season crop the maximum 35\% parasitization was recorded in $45^{\text {th }}$ standard week which was on par (33\%) in winter season crop and keep the pest infestations under control (Fig. 2).

Discussion

Studies on population dynamics of stem borer indicated that the population of egg masses was more in September and Jan (0.1 egg/plant) coinciding with growth of kharif and rabi-seasons' sorghum, respectively. The larval populations are more during Oct (0.4 larvae/plant)
Research article

Clndian Society for Education and Environment (iSee)
"Sorghum stem borer" http://www.indjst.org
Divya et al. Indian J.Sci.Technol. 
during kharif season whereas, in rabisummer it was in Feb (0.3 larvae/plant). However, the larval population was more (8\%) during kharif than the rabi-summer which is in close agreement with the report of Mohan et al. (1990). Mahadevan \& Chellaiah (1986) studied the population dynamics of $C$. partellus using light trap at Coimbatore (Tamil Nadu) and high incidence was reported in January compared to other months, especially at new moon that at the other lunar phases, and the damage was recorded more on crop sown in June or Oct. Further they reported that the maximum number of female adults was recorded than male throughout the year, it could be the reason that female insects are more attracted by light trap than male insect. A report from Maharashtra indicated that the larval population was more in winter sorghum than in rainy season sorghum, this might be due to weather condition and also the cropping pattern in that area (Annon., 1987). Further they have reported that the percentage of stem tunneling and internodes due to pupa were high (21 pupae/50 plants) only in rainy season crop. Above results were in close agreements with our records showing that the pupal population of $C$. partellus was higher in Nov (0.3 pupa/plant) during kharif (rainy season) whereas, in rabi-summer (during March), it was less $(0.2 \mathrm{pupa} / \mathrm{plant})$ (Table $1 \& 2)$. The results of our study revealed that the Chilo partellus incidence was more in Oct and Nov compared to Jan and Feb. Trehan \& Butani (1947) reported maximum damage caused by $C$. In partellus was more (7.5 to $27 \%$ ) in kharif season than in rabi-summer crop (9 to 17\%). Duale (1999) reported that the percent incidence and distribution of stem borer varied in between the states.

In Maharashtra, the highest incidence (40\%) of C. partellus was recorded in Amravati district followed by Yavatmal (39\%) in kharif season whereas, in Andhra Pradesh, it was less in Medak (31\%), followed by Mahbubnagar (30\%). Further, Singh and Sharma (1984) observed that the incidence of $C$. partellus on sweet sorghum crop in Lucknow region ranged from 38 to $63 \%$ while it was somewhat low (7.5 to $27 \%$ ) at Dharwad. The higher Getu et al. (2003) reported high percentage of parasitism of stem borers by $C$. flavipes in eastern Ethiopia than other surveyed regions, and the parasitism was significantly high. In India, Sharma et al. (1966) and Rao \& Ali (1977) have also been recorded maximum C. flavipes parasitization on larvae of $C$. partellus during Kharif. Kishore (1986) recorded $21 \%$ parasitization of $C$. partellus larvae by $C$. flavipes which is in close
Vol.3 No. 1 (Jan 2009)

ISSN: 0974- 6846

Table 2. Population dynamics of Chilo partellus and its natural enemies in sweet sorghum ecosystem during rabi - summer season.

\begin{tabular}{|c|c|c|c|c|c|c|c|c|}
\hline \multirow[t]{2}{*}{$\begin{array}{c}\text { Date of } \\
\text { observation }\end{array}$} & \multirow[t]{2}{*}{$\begin{array}{l}\text { standard } \\
\text { week }\end{array}$} & \multirow[t]{2}{*}{$\begin{array}{c}\text { No. } \\
\text { of } \\
\text { egg } \\
\text { masses }\end{array}$} & \multirow[t]{2}{*}{$\begin{array}{c}\text { No. } \\
\text { of } \\
\text { larvae }\end{array}$} & \multirow[t]{2}{*}{$\begin{array}{c}\text { No. } \\
\text { of } \\
\text { pupae }\end{array}$} & \multirow[t]{2}{*}{$\begin{array}{c}\text { No. } \\
\text { of } \\
\text { plant } \\
\text { infested }\end{array}$} & \multirow[t]{2}{*}{$\begin{array}{c}\% \\
\text { damage }\end{array}$} & \multicolumn{2}{|c|}{$\begin{array}{c}\% \\
\text { Parasiti- } \\
\text { zation } \\
\text { of natural } \\
\text { enemies }\end{array}$} \\
\hline & & & & & & & $\mathrm{Cf}$ & $\mathrm{Si}$ \\
\hline 6-12-2005 & 49 & 4 & 4 & 0 & 3 & 66 & 0 & 0 \\
\hline 13-12-2005 & 50 & 5 & 6 & 0 & 4 & 8 & 20 & 16.7 \\
\hline $20-12-2005$ & 51 & 3 & 7 & 0 & 6 & 12 & 0 & 14.3 \\
\hline $27-12-2005$ & 52 & 3 & 8 & 0 & 6 & 12 & 0 & 12.5 \\
\hline Mean & & 0.08 & 0.13 & 0 & & 10 & 5.0 & 10.9 \\
\hline $3-1-2006$ & 1 & 2 & 12 & 2 & 8 & 16 & 0 & 16.7 \\
\hline $10-1-2006$ & 2 & 4 & 15 & 3 & 8 & 16 & 0 & 20.0 \\
\hline 17-1-2006 & 3 & 2 & 19 & 6 & 10 & 20 & 0 & 31.6 \\
\hline $24-1-2006$ & 4 & 3 & 12 & 5 & 7 & 14 & 0 & 25.0 \\
\hline $31-1-2006$ & 5 & 1 & 13 & 5 & 6 & 12 & 0 & 23.1 \\
\hline Mean & & 0.05 & 0.28 & 0.08 & & 16 & 0 & 23.3 \\
\hline $7-2-2006$ & 6 & 1 & 16 & 5 & 8 & 16 & 0 & 37.5 \\
\hline 14-2-2006 & 7 & 0 & 15 & 7 & 7 & 14 & 0 & 26.7 \\
\hline $21-2-2006$ & 8 & 0 & 17 & 6 & 10 & 20 & 0 & 23.5 \\
\hline $28-2-2006$ & 9 & 1 & 19 & 11 & 9 & 18 & 0 & 26.3 \\
\hline Mean & & 0.01 & 0.34 & 0.15 & & 17 & 0 & 28.5 \\
\hline $7-3-2006$ & 10 & 0 & 10 & 11 & 6 & 12 & 0 & 20.1 \\
\hline $14-3-2006$ & 11 & 0 & 16 & 10 & 4 & 8 & 0 & 18.7 \\
\hline $21-3-2006$ & 12 & 0 & 16 & 9 & 4 & 8 & 0 & 12.5 \\
\hline $28-3-2006$ & 13 & 0 & 12 & 10 & 4 & 8 & 0 & 8.3 \\
\hline Mean & & 0 & 0.27 & 0.20 & & 9 & 0 & 14.9 \\
\hline
\end{tabular}

agreement with present study where in the mean parasitism recorded was upto $29 \%$. Higher rate of parasitization of $C$. partellus larvae by $\mathcal{S}$. inferens occurred during January (23\%) and February (28\%) and later declined during March (15\%). Several authors have recorded $S$. inferens parasitization up to $25 \%$ on $C$. partellus (Usman \& Puttarudiah (1955), Butani (1957, 1958) and Sharma et al. (1966). In the present study revealed that maximum of $29 \%$ parasitization recorded during kharif season crop and it is in close agreement with the results of Chaudhary \& Sharma (1987) and Kishore (1986) who were also recorded the highest percent parasitization (32\%) during kharif season sorghum. The parasitic effects of pupae of $C$. partellus by Tetrastichus sp. were reported by several authors (Butani 1958; Rao 1965; Greathead 1990; Mohyuddin 1990). The pupal parasitoid, Tetrastichus sp. population upto $2 \%$ was observed in present study and it was noticed in Oct $(2 \%)$ and Nov (1\%) in kharifseason.

An increased understanding of the influence of plant and associated arthropod-species diversity on pest populations will lead to the development of recommendations for utilizing natural enemies such as parasitoids and predators for $C$. partellus management. Future laboratory studies should be taken to evaluate the parasitic effect of these indigenous parasitoids in both the

Research article

CIndian Society for Education and Environment (iSee)
"Sorghum stem borer" http://www.indjst.org
Divya et al. Indian J.Sci.Technol. 
seasons on C. partellus larvae and pupae to determine the suitable weather conditions to utilize these species could be of use as recommended biological control agents in sorghum cropping systems.

\section{References}

1. Anonymous (1987) Sorghum stem borer in India and Southeast Asia. In: Intl. Workshop of Sorghum Stem Borer, at Patancheru, 17-20 Nov, ICRISAT, India. pp: 19-25.

2. Barpete RD and Shinde CB (1991) Seasonal occurrence of Apanteles flavipes (Cameron) on Chilo partellus (Swinhoe) in Madhya Pradesh. J. Insect Sci., 4, 112-116.

3. Butani DK (1957) A Tachiniid fly parasite of Chilo zonellus (Swin.). Ind. J. Entomol. 19, 62-63.

4. Butani DK (1958) Parasites and predators recorded on sugarcane pests in India. Ind. J. Entomol. 20, 270-282.

5. Chaudhary RN and Sharma VK (1987) Parasitization in diapausing larvae of Chilo partellus (Swinhoe) by Apanteles flavipes (Cameron). Ind. J. Ecol. 14, 155-157.

6. Devi N and Raj D (1996) Extent of parasitization of Chilo partellus (Swinhoe) on maize by Apanteles sp. in mid hill zone of Himachal Pradesh (India). J. Entomol. Res. 30, 171-172.

7. De Groote HW, Overholt JO, Ouma and Mugo S (2003) Assessing the impact of Bt maize in Kenya using a GIS model. Paper presented at the International Agricultural Economics Conference, Durban, $17^{\text {th }}-23^{\text {rd }}$, August. pp. 78-79.

8. Duale AH (1999) Incidence and distribution in sorghum of the spotted stem borer Chilo partellus and associated natural enemies in farmers' fields in Andhra Pradesh and Maharashtra states. Int. J. Pest Management 45(1), 3-7.

9. Durden JC (1953) Stem borer of cereal crops at Kongwa, Tanganyika 1950-1952. East Afri. Agri. J., 19, 105-119.

10. Greathead DJ (1990) Utilization of natural enemies of Chilo sp. for management in Africa. Insect Sci. Appl. 11, 749-755.

11. Getu EA, Overholt W, Kairu E and Omwega CO (2003) Evidence of the establishment of Cotesia flavipes (Hymenoptera:Braconidae), a parasitoid of cereal stemborers, and its host range expansion in Ethiopia. Bull. Entomol. Res. 93(2), 25-129.

12. ICRISAT (1992) The medium term plan. Ann. Progress Report, Vol. II. ICRISAT, AP, India. pp: 312.

13. Jotwani MG, Chaudhari S, Singh SP and Young WR (1971) Studies on resistance in sorghum against stem borer, Chilo zonellus (swin.). Investigations on Insect Pest of Sorghum and Millets. 31, 113-118.

14. Kishore P (1986) Studies on natural enemies of spotted stem borer, Sorghum newsletter, 29, 65-66.

15. Krishnamurthy B and Usman S (1954) Some insect parasites of economic importance noted in Mysore State, Ind. J. Entomol. 16, 327-343.

16. Mahadevan NR and Chellaiah S (1986) Population dynamics of the sorghum stem borer, Chilo partellus (Swinhoe) in light trap, In: Behavioral and Physiological Approaches in Pest management. (Eds. Ragupathy A \& Jayaraj S) Tamil Nadu Agri. Univ., Coimbatore, India. pp. 104-106.
17. Mohan BR, Verma AN and Singh SP (1990) Populations build up of Chilo partellus (Swinhoe) on forage sorghum in Haryana. J. Insect Sci. 3, 42-46.

18. Mote UN (1988) Correlation between the degree of damage due to stem borer, Chilo partellus (Swinhoe) and yield of sorghum grain. Ind. J. Entomol. 48, 317-358.

19. Mohyuddin Al (1990) Biological control of Chilo sp. in maize. Insect Sci. Appl. 11, 721-732.

20. Overholt WA (1998) A review of classical biological control stem borer in Africa, In: Cereal Stem Borers in Africa, Taxonomy. (Ed. Polaszek A) Natural Enemies and Control Technical Centre for Agricultural and Rural Cooperation, Wageningen, The Netherlands. pp: 545598.

21. Parrella MP, Hansen LS, Van Lenteren JC (1999) Glass house experiments In: Handbook of Biological Control. (Ed. Fisher TS) Academic Press, NY, pp. 819839.

22. Rao KP (1965) Natural enemies of rice stem borer and allied species in various parts of the world and possibilities of their use in biological control of rice stem borer in Asia. Technological Bulletin, Commonwealth Institute for Biological Control, Bangalore, 6, 1-68.

23. Rao KP and Ali M (1977) Some natural enemies of rice and sorghum stem borer (Tryporyza incertulas and Chilo partellus) in Andhra Pradesh. Ind. J. Entomol. 38, 191193.

24. Sharma K, Saxena JD and Subba Rao BR (1966) A catalogue of the hymenopterous and dipterous parasites of Chilo zonellus (Swinhoe) (Crambidae: Lepidoptera). Ind. J. Entomol. 28, 510-542.

25. Shorey HH and Hale RL (1965). Mass rearing of the larvae of nine noctuid species on a simple artificial medium. J. Econ. Entomol. 58, 522-524.

26. Singh JP and Sharma $Y$ (1984) Incidence of Chilo partellus (Swinhoe) on maize and jowar in Punjab. Punjab University Science, Res. Bull. 34, 105-114.

27. Songa JM, Bergvinson D and Mugo S (2001) Impacts of Bt-gene based resistant in maize on non-target organism in Kenya. Characterization of target and non-target organisms of Bt-gene- based resistance in two major maize growing regions in Kenya. Insect resistant maize for Africa (IRMA). Ann. Report. 4, 16-21.

28. Trehan KN and Butani DK (1947) Notes on life history bionomics and control of Chilo zonellus (Swin.) in Bombay Province. Ind. J. Entomol. 11, 47-59.

29. Usman S and Puttarudiah M (1955) A list of the insects of Mysore including the mites. Annual report, Department of Agriculture, Mysore, Karnataka, India. p. 85. 